\title{
Synthesis and structure of a carbohydrate-fused [15]-macrodilactone
}

Debjani Si and Mark W. Peczuh*

Address: Department of Chemistry, University of Connecticut, 55 North Eagleville Road, U3060, Storrs, CT 06269, USA

Email: Mark W. Peczuh*- mark.peczuh@uconn.edu

* Corresponding author

\section{Abstract}

The design, synthesis and structural characterization of a new $\alpha$-D-glucose fused [15]macrodilactone is reported. The macrolide was synthesized by a route involving sequential acylations of glucose at the C4' and C6' hydroxyl groups followed by an intramolecular Stille reaction previously established for other [15]-macrodilactones. Analysis of the X-ray crystallographic structure of the macrolide revealed a unique conformation of this macrocycle that differs from earlier models for [13]- and [15]-macrodilactones. Organizing the three planar units and the pyranose moiety into a macrocyclic ring resulted in a cup-shaped structure with planar chirality. Further, the gt conformation of the exocyclic hydroxymethyl group in the glucose unit was found to be crucial for controlling the planar chirality and, hence, governing the molecular shape and overall topology of the compound.

\section{Keywords}

macrocycle; carbohydrate; macrodilactone; planar chirality; topology; asymmetric center 


\section{Introduction}

Carbohydrate-fused macrocycles, featuring one or more carbohydrate moieties as an integral part of a macrocyclic framework, represent a group of compounds of high biological relevance [1-3]. When a carbohydrate (mono-, di-, or tri-saccharide) is incorporated into a macrocycle, its essential characteristics contribute to the overall properties of the macrocycle. The sugar moieties, themselves being cyclic in nature, exert a conformational constraint on the structure and thereby help to rigidify the system, potentially making them better ligands to bind protein targets [4]. At the same time, monosaccharides are structurally diverse with easily tuneable functionalities that facilitate binding to biomolecules. Carbohydrate residues also improve the overall pharmacokinetic properties of macrocycles. Examples of naturally occurring, sugar-embedded macrocycles include glycolipids (sophorolipid lactone, tricolorins, merremosides), glycophanes (cycloviracin $B_{1}$, glucolipsin A), cyclic oligosaccharides (cyclodextrins), cyclic glycopeptides and cyclic aminoglycosides $[1,5]$. In recent years, carbohydrate-fused synthetic macrocycles have gained significant interest amongst synthetic chemists and they have been studied for their potential applications, particularly in biological systems [6-13].

Since the structural features of a macrocycle are directly associated with its biological properties, we investigate the structural principles that control macrocycle shape and topology. We, and others, have endeavoured to describe rules that define and even predict the shape taken up by a macrocycle where a carbohydrate is part of the structure [12-19]. In this context, we have discovered that individual components such as ring size (number of atoms in the macrocyclic ring), the nature and arrangement of multi-atom planar units (e.g., alkenes, esters/amides, enones/enoates), and the absolute configuration of key asymmetric centers present in the backbone influence shape and topology of macrocycles.

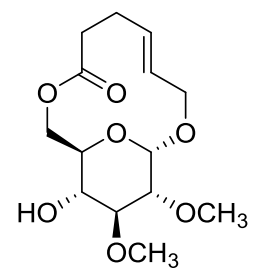

1

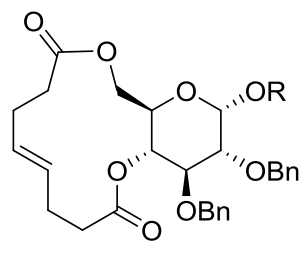

$2 \mathrm{R}=n-\mathrm{C}_{8} \mathrm{H}_{17}$ $3 \mathrm{R}=\mathrm{CH}_{3}$

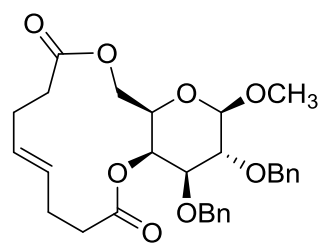

4

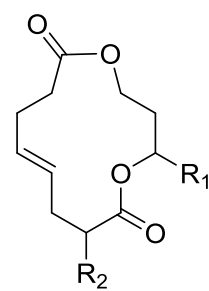

$5 \mathrm{R}_{1}=\mathrm{CH}_{3}, \mathrm{R}_{2}=\mathrm{H}$ $6 \mathrm{R}_{1}=\mathrm{H}, \mathrm{R}_{2}=\mathrm{Ph}$

Figure 1. Previously characterized [12]- and [13]-macrodilactones.

Specifically, we have synthesized and characterized macrocycles such as 1-6 depicted in Figure 1. The $\alpha$-configured [12]-macrolactone 1, for example, showed antibiotic activity against some Gram positive organisms [14]; also, octyl- $\alpha$-glucoside fused [13]-macrodilactone 2 inhibited cell-migration of breast cancer cells [15]. We have mostly focused on developing models to define macrocycle structure, however, using the [13]-macrodilactones such as 2-6 as the basis for our investigation. We have demonstrated how individual structural components influence the shape and topology of 
the macrocycles. [13]-Macrodilactones 2-6 are comprised of three four-atom planar units, a $\mathrm{sp}^{3}$ hybridized hinge atom, and asymmetric centers. It was observed that the interplay between these components gave rise to planar chirality in [13]-macrodilactones, and the handedness of the twist was determined by the absolute configuration of only one asymmetric center, at either C2 (2-5) or C7 (6), present in the macrocycles [16-21].

We recently tested our understanding of the rules for macrocyclic structure by applying them to a new motif - a larger [15]-macrodilactone. Compound 7 (Fig. 2) is a representative example. Compound 7 and related analogs were synthesized by a relatively straightforward route that involved sequential acylations of a 1,3-diol followed by an intramolecular Stille macrocyclization [22]. The key feature that was being tested was whether a six-atom 1,3-diene unit could substitute for a four-atom (alkene) planar unit (Compare cartoons at left and right ends of Fig. 2). We considered 7 to be a ring-expanded version of C2-substituted [13]-macrodilactone 5 . As was the case for $\mathbf{5}$, the absolute configuration of the asymmetric center was found to be pivotal in governing the handedness of the planar chirality and thus, in controlling the overall shape and topology of 7 .

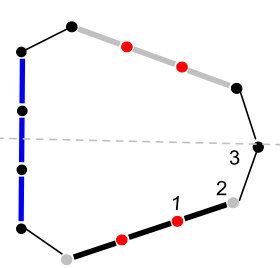

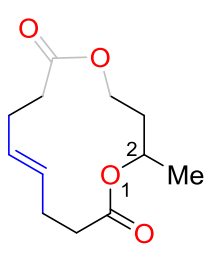

5

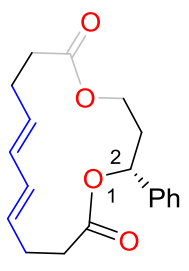

7

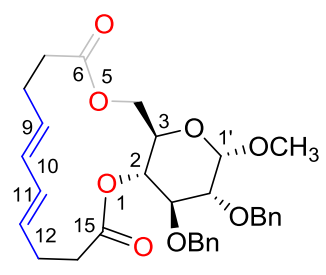

8

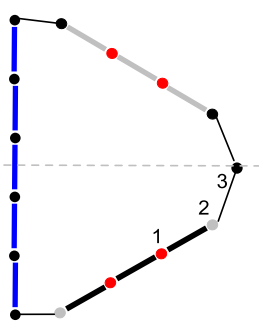

Figure 2. [13]-Macrodilactone 5, 2R-phenyl [15]-macrodilactone 7 and methyl $\alpha$-D-glucose [15]macrodilactone 8.

In this work, we report on a system that is inconsistent with the model we have developed to explain the structures of the [13]- and [15]-macrodilactones. We synthesized D-glucose-fused [15]macrodilactone $\mathbf{8}$ with the expectation that its structural properties would be in line with those we had previously reported. We found, however, that the pyranose ring constrains a key torsion and changes the conformation of the macrocycle and consequently the overall structure of the molecule. We detail the synthesis, structural, and functional characterization of $\mathbf{8}$ here and attempt to reconcile its features with the trends observed for other, related macrocycles we have investigated.

\section{Results and Discussion}

2.1 Synthesis of the new [15]-macrodilactone

The synthesis of D-glucose-fused [15]-macrodilactone 8 followed the strategy we previously established [22]. It started with the chemoselective acylation of the C6 hydroxyl group of known diol 9[23] with 4-pentynoic acid 10 to afford 11 (65\%) (Scheme 1). Bromination of the terminal alkyne of 11 followed by hydrostannation of the resulting bromoalkyne 12 gave vinylstannane 13 in $55 \%$ yield [24]. A second esterification with 4E-5-iodopentenoic acid 14 [25-29] furnished Stille precursor 15 (76\%). Finally, intramolecular Stille coupling [30] using $\mathrm{Pd}_{2}(\mathrm{dba})_{3}$ and $\mathrm{Ph}_{3} \mathrm{As}$ completed the 
synthesis of 8 in $42 \%$ yield. Like [15]-macrodilactone 7, the newly generated 1,3-diene in glucosederived macrolide 8 was found to exist in trans-trans geometry from its ${ }^{1} \mathrm{H}$ and ${ }^{13} \mathrm{C}$ NMR data. At this point, though, it was difficult to draw any conclusion about the s-cis and s-trans geometry of the diene.

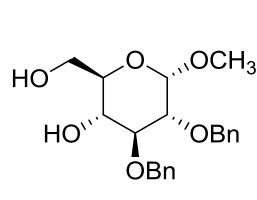

9

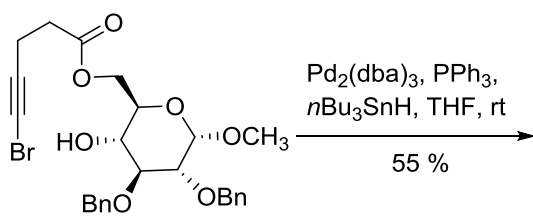

12

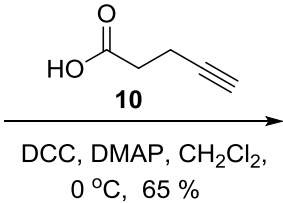

$0^{\circ} \mathrm{C}, 65 \%$

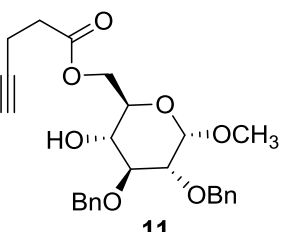

11

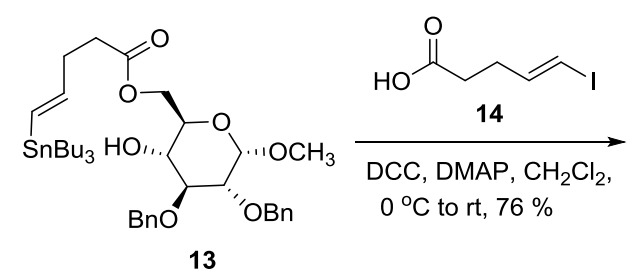

13
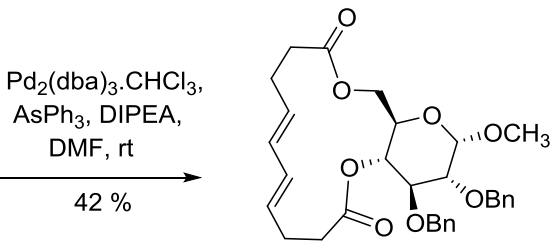

8

Scheme 1. Synthesis of glucose-fused [15]-macrodilactone 8.

\subsection{Structural analysis of the new [15]-macrodilactone from X-ray data}

[15]-Macrodilactone 8 was obtained as an off-white solid that, upon recrystallization from an ethyl acetate-hexane mixture, provided crystals of suitable quality for X-ray crystallography. The structure of 8 from the crystallographic data is shown in Figure 3. Analysis of the crystal structure revealed several structural features of the 15-membered ring as well as of the fused carbohydrate moiety. In comparison to phenyl substituted macrocycle 7, there are a few similarities and some differences between the two structures. The most notable resemblance was that, like macrocycle 7 , each of the ester groups in 8 formed a plane of four atoms and the 1,3-diene unit, which adopted an s-trans geometry, formed a plane of six atoms. These multi-atom planar units made the macrocyclic structure fairly rigid by restricting number of freely rotatable bonds in it. In a cyclic array they were disposed at an angle to each other giving rise to a non-coplanar structure. 

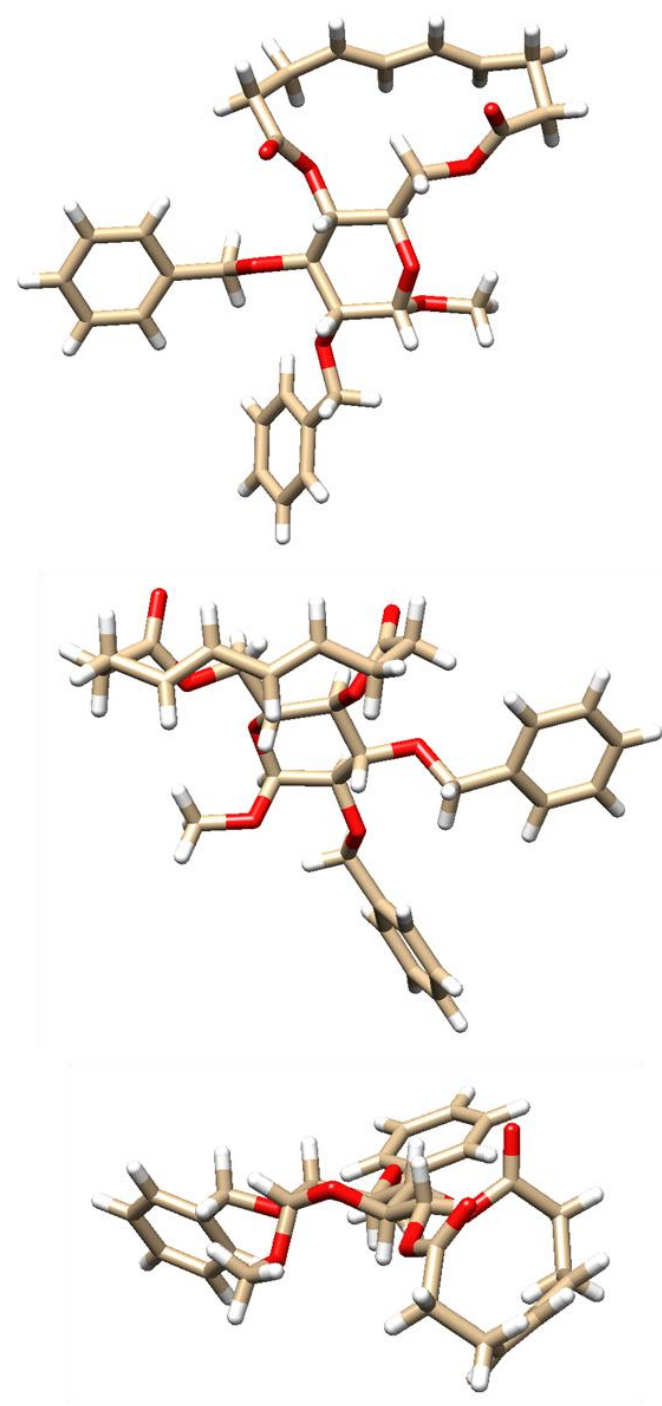

8
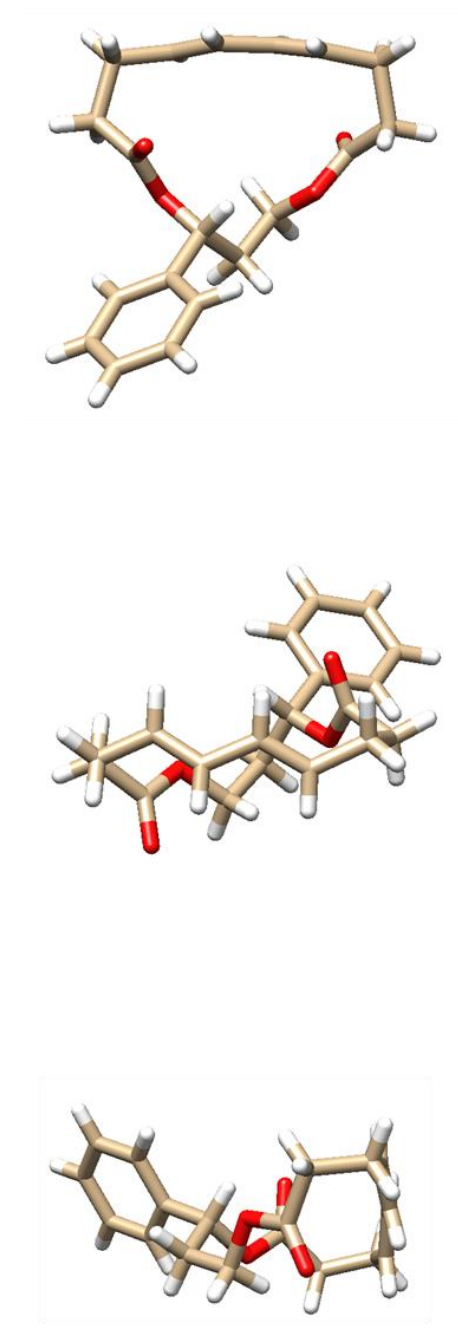

7

Figure 3. X-ray crystallographic structure of methyl $\alpha$-D-glucose [15]-macrodilactone 8 and $2 R$-phenyl [15]macrodilactone 7.

Among the differences, most significant one was that, in 8, the two ester carbonyls were oriented parallel to each other compared to their antiparallel orientation in macrocycle 7. From our prior experience with [13]-macrodilactones, it was inferred that the parallel orientation of two carbonyls didn't represent a ribbon like structure, but rather manifested a cup shape, originating from an attenuation of the screw-sense in diol unit [18]. The 1,3-diol unit of 8 was embedded in the glucose ring, which itself adopted $a{ }^{4} \mathrm{C}_{1}$ chair conformation; the preferred conformation of the pyranose logically has some influence on the shape of the fused macrocycle. With consideration to the hydroxymethyl group of pyranose sugars [31-34], the glucose hydroxymethyl group (C3-C4 bond in the [15]-macrodilactone numbering) was in the gt conformation. The gt conformation is favored on stereoelectronic grounds[31] and was observed in the structure of 8 (See Supplementary Information for Newman projections). The length of the diene unit required the hydroxymethyl group to maintain this conformation. As a result, atoms C2, C3 and C4 (macrocycle numbering) in 8 were nearly coplanar, along with ester oxygens $\mathrm{O} 1$ and $\mathrm{O} 5$. These same atoms were also nearly coincident with the macrocyclic ring plane. Torsion angles related to these atoms, O1-C2-C3-C4 
and $\mathrm{C} 2-\mathrm{C} 3-\mathrm{C} 4-\mathrm{O} 5$, were $+63.78^{\circ}$ and $-162.20^{\circ}$ respectively. Similar angles in 7 were $+64.57^{\circ}$ and $+67.57^{\circ}$, respectively. A complete list of all the torsional angles is shown in Table 1.

The near planarity of $\mathrm{O} 1$ and $\mathrm{O} 5$ in this conformation dampened the magnitude of the screw sense of the diol unit in macrocycle 8. Additionally, the presence of pyranose unit in $\mathbf{8}$ introduced an extent of rigidity in the macrocyclic structure reducing its flexibility relative to 7 . In macrocycle 8 the plane of the macrocycle was found to be oriented at an angle relative to the plane of the glucose unit. As a result of all these factors the molecule $\mathbf{8}$ adopted a cupped structure with the carbonyls of the macrocycle pointing outward from the convex face and the aglycone methyl pointing inward along the concave face. However, despite the absence of a significant twist in the diol unit and its related flexibility, the macrocycle 8 as a whole still possessed a planar chirality. We suspected it was the specific gt conformation of the hydroxymethyl group of pyranose unit that guided the three multi-atom planar units to fold around the axis of the macrocycle in such a way that two carbonyls oriented themselves in parallel and a cup-shaped structure was generated for [15]-macrodilactone 8.

Table 1. Dihedral angles in [15]-macrodilactone 8.

\begin{tabular}{cc}
\hline Atoms of Dihedral $^{a}$ & Angle $\left.^{\circ}\right)$ \\
\hline O1-C2-C3-C4 & 63.78 \\
C2-C3-C4-O5 & -162.20 \\
C3-C4-O5-C6 & 179.77 \\
C4-O5-C6-C7 & -163.30 \\
O5-C6-C7-C8 & 126.20 \\
C6-C7-C8-C9 & -53.47 \\
C7-C8-C9-C10 & 99.80 \\
C8-C9-C10-C11 & -164.19 \\
C9-C10-C11-C12 & 175.59 \\
C10-C11-C12-C13 & 173.14 \\
C11-C12-C13-C14 & 126.54 \\
C12-C13-C14-C15 & -101.32 \\
C13-C14-C15-O1 & -32.51 \\
C14-C15-O1-C2 & -172.17 \\
C15-O1-C2-C3 & -126.17 \\
\hline${ }^{a}$ For atom numbering refer to 8 in Figure
\end{tabular}

The graphical depiction of both the [15]-macrodilactones 8 and 7 in Figure 4 is a tool to chart the displacement of the atoms of the macrocycle relative to a plane. The graph helps illustrate the 
differences in conformation between two macrocycles. Similar graphical representations were originally applied for porphyrins [35] and later adopted to compare the structures of different [13]macrodilactones[21]. Here the conformation of each macrocycle is represented in a two-dimensional map. The macrocycle is virtually "cut" through C3 atom and then unfolded to show the positions of the ring atoms. Deviations of ring atoms were measured with respect to a mean plane defined by three ring atoms, C3, C6 and C15, and plotted against the atom numbers. From the graphs (c and d in Fig. 4), the difference between the two macrocyclic structures were evident. While macrocycle 7 followed a pattern previously observed for "ribbon" shaped [13]-macrodilactones, macrocycle 8 exhibited the pattern typical of "cup"-shaped [13]-macrodilactones characterized by the parallel orientation of two of their carbonyl groups[21]. Based on the above observation it was established that [15]-macrodilactone 8 adopted a "cup"-shaped planar chiral structure.
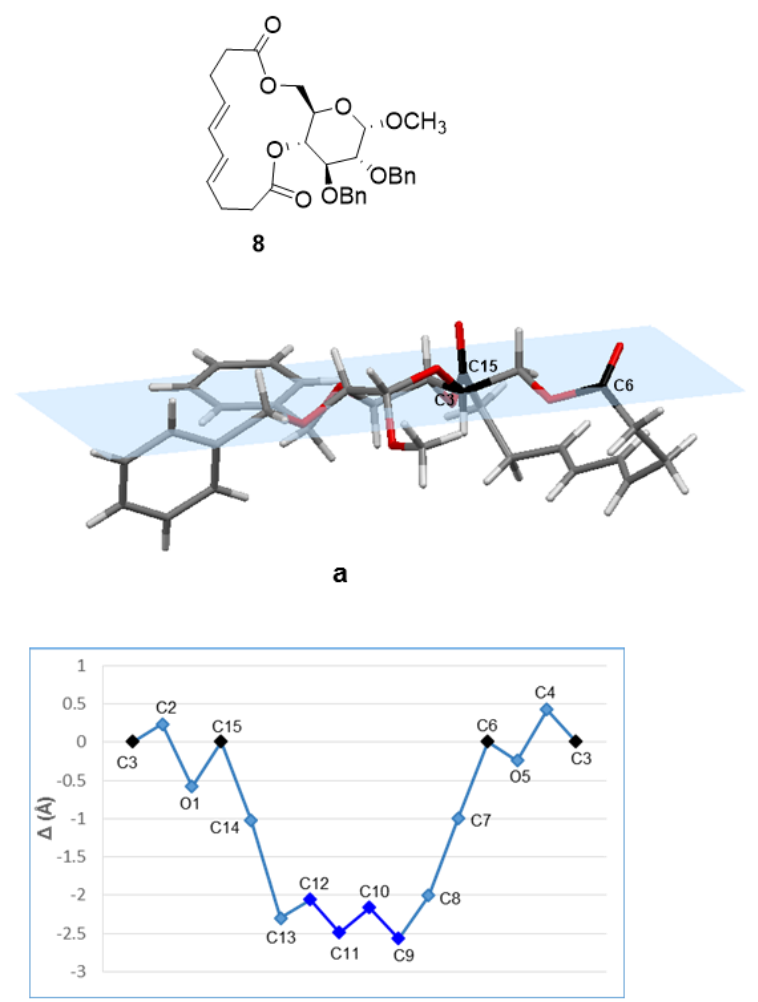

c

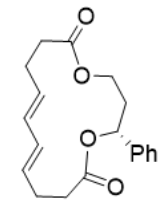

7
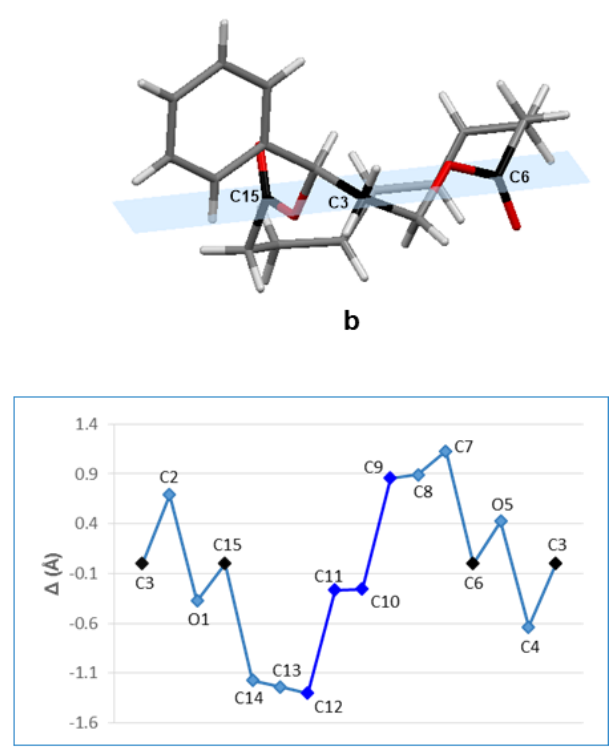

d

Figure 4. The C3-C6-C15 planes passing through [15]-macrodilactones 8 and 7 repectively, are depicted in (a) and (b). In (c) and (d), conformational maps of the two macrocycles are shown.

Additionally, atoms in the two esters and the diene unit of $\mathbf{8}$ were not strictly co-planar but were much closer to such a disposition as compared to 7. In macrolide 7, although the ester units were nearly planar (dihedral angles related to atoms C14-C15-O1-C2 and C4-O5-C6-C7 were 179.43 and 175.55 respectively), the six-carbon diene unit exhibited bowing with an average RMSD value between the atoms and the planes of 0.1328 (See Supporting Information.). As observed in glucose-fused macrocycle 8 , the dihedral angles related to these atoms were -163.30 and -172.17 respectively and the RMSD value related to diene moiety was 0.1070 representing some extra curvatures in ester units but higher planarity in the diene unit compared to macrolide 7 . Further, the 
distance between C3 and central alkene carbons, C10 and C11 were found to be shorter in glucose-fused system 8 than in macrolide 7 (in $8 \mathrm{~d}_{\mathrm{C} 3-\mathrm{C} 10}$ : $4.518 \AA$, $\mathrm{d}_{\mathrm{C} 3-\mathrm{C} 11}: 4.133 \AA$; in $7 \mathrm{~d}_{\mathrm{C} 3-\mathrm{C} 10}$ : $5.122 \AA, d_{\mathrm{C} 3-\mathrm{C} 11}: 5.130 \AA$ ). On the basis of all the above observations, [15]-macrodilactone 8 displayed a narrow, elongated, and rigid structure compared to macrodilactone 7. Perhaps it was because of the rigidity of the overall system that macrocyclic ring closure became comparatively more difficult and it reflected in the lower yield of the intramolecular Stille coupling for [15]macrodilactone 8 compared to its non-sugar analogs.

\subsection{Regio- and diastereoselective epoxidation of the macrocyclic diene unit}

Analogous to 7, however, glucose-fused macrocycle 8 was found to expose only one face of its diene to the outer environment [36-40]. Macrocycle 8 positioned the opposite face of the diene outward even though the configuration at $\mathrm{C} 2$ (that in $\mathbf{7}$ was the key center controlling the planar chirality) was the same in both the macrocycles. In macrolide 8 the $R$-configuration of glucose C4' induced the pro-S,S-S,S-face of the diene unit to be exposed to the outer environs and thus, reactions were expected to occur in that face. But in our previous study we showed that in [15]macrodilactone 7 , for the $(R)$-configuration of $\mathrm{C} 2$, it was the pro- $R, R-R, R$-face of the diene which underwent epoxidation [22]. Our rationale for this observation was that the parallel orientation of the carbonyls in $\mathbf{8}$ played a role in flipping the exterior face.

To fully investigate the influence of the topology on the facial selectivity of the diene unit, we decided to explore epoxidation chemistry in macrocycle 8 . While epoxidation of 7 proceeded with high facial selectivity, it was not regioselective [22]. Because both alkenes of the diene in 7 positioned the pro- $R, R$ face to the exterior environment, transesterification of the mixture of regioisomers gave rise to only one enantiomer of the diester epoxide. When [15]-macrodilactone 8 was subjected to epoxidation using DMDO generated in situ from acetone and oxone (Scheme 2), epoxide 16 was isolated as a white solid in $67 \%$ yield as the sole product of the reaction. Remarkably, epoxidation of $\mathbf{8}$ occurred with both high facial diastereoselectivity and high regioselectivity. ${ }^{1} \mathrm{H}$ and ${ }^{13} \mathrm{C}$ NMR spectra of epoxide 16 were consistent with the structure shown, where epoxidation took place only at the 9,10-alkene, located away from carbohydrate fused region of the macrolide $\mathbf{8}$. However, at this point the reason behind the observed regioselectivity in the epoxidation of $\mathbf{8}$ is not fully apparent.

As observed earlier for other [13]-macrodilactones and [15]-macrodilactones, facial selectivities of the alkene and diene units originated via macrocyclic diastereocontrol[36-40]. Being present in a rigid cyclic structure, the planar 1,3-diene unit in macrocycle 8 was not able to rotate around its own axis. As a result, only one of its faces came in contact with outside environment while the other face was blocked by the macrocyclic framework. Among two which face would be pointed outward was determined by the specific planar chirality the macrocycle 8 adopted. We reasoned that it was not only the absolute configuration of the asymmetric center present at $\mathrm{C} 2$, but a combination of it along with other factors such as the gt conformation of the hydroxymethyl group of fused glucose system and the presence of long diene unit in cyclic structure influenced the planar chirality in [15]- 
macrodilactone 8. As predicted from the X-ray crystallographic data of [15]-macrodilactone $\mathbf{8}$, the planar chiral structure adopted by the macrocycle favoured only the $S, S-S, S$ face of its diene to undergo epoxidation.
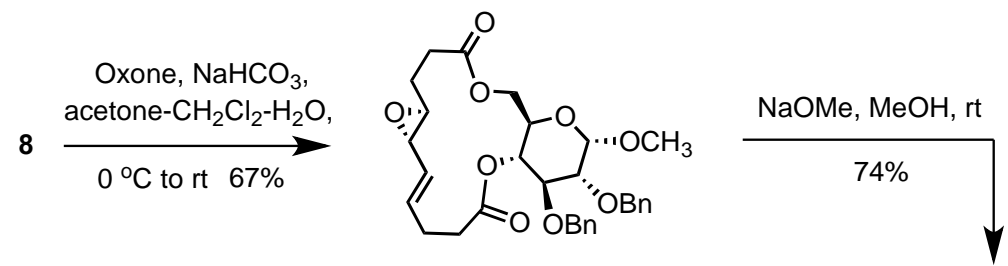

16

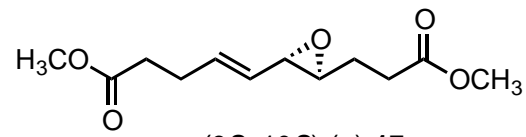

$(9 S, 10 S)-($ )-17
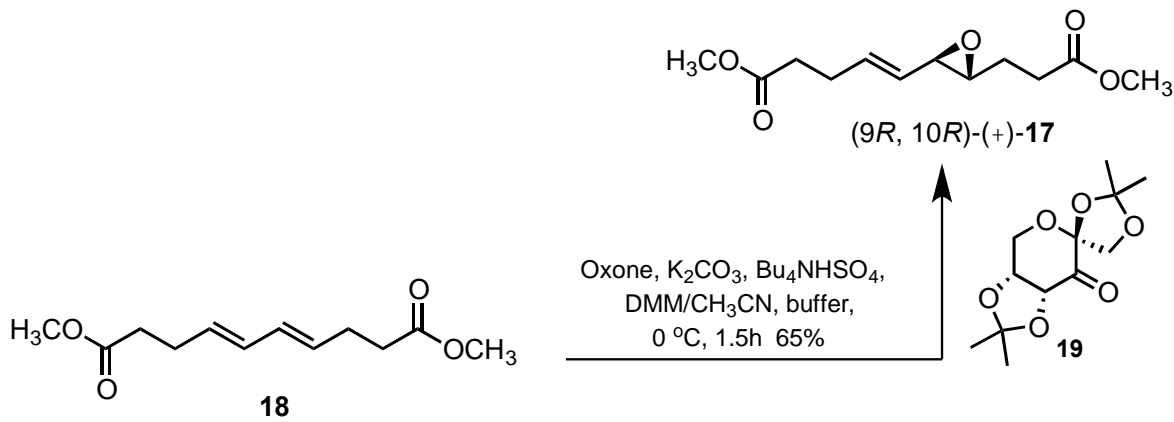

Scheme 2. Epoxidation of glucose-fused [15]-macrodilactone 8.

To establish the absolute configuration of epoxide 16, a strategy originally used for [13]macrodilactones [16] and [15]-macrodilactone 7 [22] was employed. A transesterification reaction of macrocyclic epoxide $\mathbf{1 6}$ under Zemplén conditions provided the epoxyalkene (-)-17 as a single enantiomer in $74 \%$ yield (Scheme 2 ). This result clearly suggested that the epoxidation reaction of macrocyclic diene 8 was completely face-selective. Further, the newly generated epoxyalkene (-)17 was compared with the epoxyalkene $(+)-17$ resulted from Shi epoxidation $[41,42]$ of diene 18 , synthesized previously by a parallel route [22]. The epoxy alkene (-)-17 matched with epoxide (+)17 in all respects such as ${ }^{1} \mathrm{H},{ }^{13} \mathrm{C}$ NMR except the optical rotation values. The optical rotation of epoxyalkene $(-)-17$ was measured to be $[\alpha]_{D}{ }^{20}=-23.2\left(c 0.6, \mathrm{CHCl}_{3}\right)$, while the optical rotation of epoxide $(+)-17$ was $[\alpha]_{D}^{20}=+25.5\left(c 0.6, \mathrm{CHCl}_{3}\right)$. Thus, based on the comparison of both the epoxides, absolute configuration of glucose-fused macrocyclic epoxide 16 were assigned as $9 S$, $10 S$.

\section{Conclusion}

We have described the design, synthesis and characterization of new D-glucose-fused [15]macrodilactone 8. A structural analysis of $\mathbf{8}$ suggested that this macrocycle differed from other [15]macrodilactones in a significant way, adopting a cup-shaped structure. The presence of the fused glucose moiety and its inherent preference for the gt rotamer of its exocyclic hydroxymethyl group 
attenuated the magnitude of the screw sense of the macrocycle. Moreover, the six-atom planar 1,3diene unit reinforced the rotameric preference. Together these factors fostered the observed cupshaped topology, albeit with planar chirality. In [15]-macrodilactone 8, it was not only the absolute configuration of $\mathrm{C}^{2}$ ( $\mathrm{C}^{\prime}$ ' in glucose system) in the macrocyclic structure that influenced the planar chirality, but possibly a combination of $\mathrm{C} 2$ and the fused glucose ring together guided the three planar units to arrange in a specific way to generate the observed planar chirality. Specifically, deviation of $\mathbf{8}$ from the topology established by related macrocycle $\mathbf{7}$ was most likely due to the following factors: 1 - Rotameric preferences of the exocyclic group of the pyranose that reduced the screw sense of the [15]-macrodilactone. This preference was reinforced by the need to accommodate the longer diene unit of 8 in comparison to the [13]-macrodilactone analogs such as 2-4. 2 - The fusion of the [15]-macrodilactone with the pyranose forces both rings to accommodate each other to minimize the overall structure. That is, the extra ring (the glucose) will naturally rigidify bond rotations that affect the conformation of the macrocycle.

The results reported here have significance for the design of new macrocyclic ligands with specific shapes that can interact effectively with the targeted protein surfaces. Further, deprotection of the hydroxyl groups of the glucose unit in $\mathbf{8}$, would probably result in a macrocyclic ligand with better physicochemical properties $[43,44]$. The final deprotections of sugar hydroxyls and the analysis of the resulting macrocycles in biological system are in progress in our lab and will be reported in due course.

\section{Experimental}

\subsection{General Methods}

Unless and otherwise noted, all reactions were performed at room temperature (rt) under nitrogen $\left(\mathrm{N}_{2}\right)$ atmosphere. All commercial available reagents and solvents were used as it is. All reactions were monitored by TLC (silica gel HL, w/UV254, 250 $\mu \mathrm{m}$ ) and visualized either under UV lamp or by charring with 2.5\% p-anisaldehyde in $\mathrm{H} 2 \mathrm{SO} 4, \mathrm{AcOH}$ and $\mathrm{EtOH}$ solutions or by staining with alkaline $\mathrm{KMnO} 4$ solutions. Flash chromatography was performed on silica gel (230-400 ̊). Melting points were recorded on Electrothermal melting point apparatus, and are uncorrected. Optical rotations were measured on Jasco P-2000 polarimeter using the sodium D line. ${ }^{1} \mathrm{H}$ NMR spectra were collected at $400 \mathrm{MHz}$ with chemical shift referenced the residual peak in $\mathrm{CDCl}_{3}(\delta \mathrm{H} 7.26 \mathrm{ppm}) .{ }^{13} \mathrm{C}$ NMR spectra were collected at $100 \mathrm{MHz}$ and referenced to residual peak in $\mathrm{CDCl}_{3}$ ( $\left.\delta \mathrm{C} 77.16 \mathrm{ppm}\right)$. Mass spectra were obtained from AccuTOF high resolution mass spectrometer with DART source.

\subsection{Methyl 2,3-di-O-benzyl-6-O-(4-pentyn)oyl- $\alpha$-D-glucoside 11}

A cooled solution of DCC (266 mg, $1.3 \mathrm{mmol})$ and DMAP (15 mg, $0.1 \mathrm{mmol})$ in anhyd. $\mathrm{CH}_{2} \mathrm{Cl}_{2}(5$ $\mathrm{mL})$ at $0{ }^{\circ} \mathrm{C}$ was treated with 4-pentynoic acid $10(208 \mathrm{mg}, 1.2 \mathrm{mmol})$. The resulting mixture was stirred at same temp for $30 \mathrm{~min}$ before a solution of 1, 3-diol 9 (440 mg, $1.2 \mathrm{mmol})$ in anhyd. $\mathrm{CH}_{2} \mathrm{Cl}_{2}$ 
$(10 \mathrm{~mL})$ was introduced and the mixture was stirred further at $0{ }^{\circ} \mathrm{C}$ for $4 \mathrm{~h}$. The reaction mixture was filtered through a pad of Celite and washed with $\mathrm{CH}_{2} \mathrm{Cl}_{2}$. The filtrate was evaporated to give the crude product which on silica gel column chromatography (3:2 Hex: EtOAc) provided ester 11 (350 $\mathrm{mg}, 65 \%)$ as white amorphous solid. Rf 0.20 (3:1 Hex: EtOAc); mp $69{ }^{\circ} \mathrm{C}$; $[\alpha]_{\mathrm{D}}^{20}:+4.0\left(c 0.4, \mathrm{CHCl}_{3}\right)$; ${ }^{1} \mathrm{H}$ NMR $\left(400 \mathrm{MHz}, \mathrm{CDCl}_{3}\right): \delta \mathrm{ppm} 7.37-7.29(\mathrm{~m}, 10 \mathrm{H}), 4.99(\mathrm{~d}, J=11.4 \mathrm{~Hz}, 1 \mathrm{H}), 4.77(\mathrm{~d}, J=12.1$ $\mathrm{Hz}, 1 \mathrm{H}), 4.74(\mathrm{~d}, J=11.4 \mathrm{~Hz}, 1 \mathrm{H}), 4.66(\mathrm{~d}, J=12.1 \mathrm{~Hz}, 1 \mathrm{H}), 4.61(\mathrm{~d}, J=3.5 \mathrm{~Hz}, 1 \mathrm{H}), 4.42(\mathrm{dd}, J=$ 12.0, $4.8 \mathrm{~Hz}, 1 \mathrm{H}), 4.27$ (dd, $J=12.0,2.1 \mathrm{~Hz}, 1 \mathrm{H}), 3.78$ (t, $J=9.2 \mathrm{~Hz}, 1 \mathrm{H}), 3.75-3.72(\mathrm{~m}, 1 \mathrm{H}), 3.49$ (dd, $J=9.5,3.6 \mathrm{~Hz}, 1 \mathrm{H}$ ), $3.42(\mathrm{dd}, J=9.7,9.0 \mathrm{~Hz}, 1 \mathrm{H}), 3.38(\mathrm{~s}, 3 \mathrm{H}), 2.60-2.56(\mathrm{~m}, 2 \mathrm{H}), 2.51-2.47$ $(\mathrm{m}, 2 \mathrm{H}), 1.94(\mathrm{t}, \mathrm{J}=2.6 \mathrm{~Hz}, 1 \mathrm{H}) ;{ }^{13} \mathrm{C} \mathrm{NMR}\left(100 \mathrm{MHz}, \mathrm{CDCl}_{3}\right): \delta \mathrm{ppm} 172.1,138.7,138.0,128.7$, 128.6, 128.2, 128.1, 128.0, 98.3, 81.2, 79.6, 75.6, 73.3, 70.0, 69.4, 69.3, 63.6, 55.4, 33.3, 14.4; TOF HRMS (DART): $m / z$ for $\mathrm{C}_{26} \mathrm{H}_{34} \mathrm{NO}_{7}\left[\mathrm{M}+\mathrm{NH}_{4}\right]^{+}$calcd. 472.2335, found 472.2313 .

\subsection{Methyl 2,3-di-O-benzyl-6-O-(5-bromo-4-pentyn)oyl- $\alpha$-D-glucoside 12}

To a solution of ester $11(1.7 \mathrm{~g}, 3.8 \mathrm{mmol})$ in dry acetone $(16 \mathrm{~mL})$ was added $N$-bromosuccinimide (750 mg, $4.2 \mathrm{mmol}$ ) and $\mathrm{AgNO}_{3}(66 \mathrm{mg}, 0.4 \mathrm{mmol}$ ) at room temperature. The reaction mixture was stirred for $4 \mathrm{~h}$ in dark. It was then filtered through a pad of Celite and the filtrate was evaporated. The residue was diluted with EtOAc and washed with water. The water part was separated and extracted with EtOAc $(3 \times 20 \mathrm{~mL})$. The combined organic parts were washed with brine, dried over anhydrous $\mathrm{Na}_{2} \mathrm{SO}_{4}$, filtered, and concentrated. Silica gel column chromatography (2:1 Hex: EtOAc) provided the bromoalkyne $12(1.8 \mathrm{~g}, 88 \%)$ as thick liquid. Rf $0.20\left(3: 1 \mathrm{Hex}\right.$ : EtOAc); $[\alpha]_{\mathrm{D}}^{20}:+30.6$ (c 0.8, $\left.\mathrm{CHCl}_{3}\right) ;{ }^{1} \mathrm{H}$ NMR (400 MHz, $\left.\mathrm{CDCl}_{3}\right): \delta \mathrm{ppm} 7.38-7.29(\mathrm{~m}, 10 \mathrm{H}), 5.00(\mathrm{~d}, J=11.4 \mathrm{~Hz}, 1 \mathrm{H}), 4.77$ $(\mathrm{d}, J=12.1 \mathrm{~Hz}, 1 \mathrm{H}), 4.73(\mathrm{~d}, J=11.3 \mathrm{~Hz}, 1 \mathrm{H}), 4.66(\mathrm{~d}, J=12.1 \mathrm{~Hz}, 1 \mathrm{H}), 4.61(\mathrm{~d}, J=3.5 \mathrm{~Hz}, 1 \mathrm{H})$, 4.40 (dd, $J=12.1,5.0 \mathrm{~Hz}, 1 \mathrm{H}$ ), 4.28 (dd, $J=12.1,1.9 \mathrm{~Hz}, 1 \mathrm{H}$ ), 3.80-3.73 (m, 2H), 3.50 (dd, $J=9.5$, $3.5 \mathrm{~Hz}, 1 \mathrm{H}$ ), 3.42 (dd, $J=9.6,2.5 \mathrm{~Hz}, 1 \mathrm{H}), 3.38(\mathrm{~s}, 3 \mathrm{H}), 2.58-2.49(\mathrm{~m}, 4 \mathrm{H}), 2.38(\mathrm{~d}, J=2.8 \mathrm{~Hz}, 1 \mathrm{H})$; ${ }^{13} \mathrm{C} \mathrm{NMR}\left(100 \mathrm{MHz}, \mathrm{CDCl}_{3}\right): \delta \mathrm{ppm} 171.9,138.7,138.1,128.7,128.6,128.2,128.1,128.0,98.3$, 81.2, 79.6, 75.6, 73.3, 70.0, 69.3, 63.6, 55.4, 33.0, 15.6; TOF HRMS (DART): $\mathrm{m} / \mathrm{z}$ for $\mathrm{C}_{26} \mathrm{H}_{33} \mathrm{BrNO}_{7}$ $\left[\mathrm{M}+\mathrm{NH}_{4}\right]^{+}$calcd. 552.1424, found 552.1426.

\subsection{Methyl 2,3-di-O-benzyl-6-O-[(5-tributyl-stannyl)-4E-penten]oyl- $\alpha$-D-glucoside 13}

To a solution bromoalkyne $12(2.0 \mathrm{~g}, 3.8 \mathrm{mmol})$ in THF $(36 \mathrm{~mL})$ were added $\mathrm{Pd}_{2}(\mathrm{dba})_{3}(174 \mathrm{mg}, 0.2$ $\mathrm{mmol}$ ) and $\mathrm{PPh}_{3}(230 \mathrm{mg}, 0.9 \mathrm{mmol})$ at room temperature. The resulting solution was stirred for 15 min before $n \mathrm{Bu}_{3} \mathrm{SnH}(2.2 \mathrm{~mL}, 8.4 \mathrm{mmol})$ was added over a period of $30 \mathrm{~min}$ and it was further stirred for $12 \mathrm{~h}$. The reaction mixture was concentrated in vacuo and purified by silica gel column chromatography (4:1 Hex: EtOAc) to afford vinylstannane $13(1.6 \mathrm{~g}, 55 \%)$ as pale yellow oil. Rf 0.40 (3:1 Hex: EtOAc); $[\alpha]_{D}{ }^{20}:+39.5\left(c \quad 0.6, \mathrm{CHCl}_{3}\right) ;{ }^{1} \mathrm{H} \mathrm{NMR}\left(400 \mathrm{MHz}, \mathrm{CDCl}_{3}\right): \delta$ ppm 7.36-7.29 (m, 10H), $5.93(\mathrm{~s}, 2 \mathrm{H}), 4.99$ (d, $J=11.3 \mathrm{~Hz}, 1 \mathrm{H}), 4.77$ (d, $J=12.6 \mathrm{~Hz}, 1 \mathrm{H}), 4.74(\mathrm{~d}, J=11.7 \mathrm{~Hz}, 1 \mathrm{H})$, $4.66(\mathrm{~d}, J=12.1 \mathrm{~Hz}, 1 \mathrm{H}), 4.62(\mathrm{~d}, J=3.4 \mathrm{~Hz}, 1 \mathrm{H}), 4.40(\mathrm{dd}, J=12.0,4.8 \mathrm{~Hz}, 1 \mathrm{H}), 4.23(\mathrm{dd}, J=$ 12.0, $1.7 \mathrm{~Hz}, 1 \mathrm{H}$ ), 3.79 (t, $J=9.2 \mathrm{~Hz}, 1 \mathrm{H}$ ), 3.73 (ddd, $J=9.9,4.7,2.0 \mathrm{~Hz}, 1 \mathrm{H}$ ), 3.50 (dd, $J=9.5,3.4$ 
$\mathrm{Hz}, 1 \mathrm{H}), 3.42(\mathrm{dd}, J=9.7,2.6 \mathrm{~Hz}, 1 \mathrm{H}), 3.38(\mathrm{~s}, 3 \mathrm{H}), 2.46-2.44(\mathrm{~m}, 4 \mathrm{H}), 1.55-1.43(\mathrm{~m}, 6 \mathrm{H}), 1.41-1.24$ $(\mathrm{m}, 6 \mathrm{H}), 0.94-0.83(\mathrm{~m}, 15 \mathrm{H}) ;{ }^{13} \mathrm{C}$ NMR $\left(100 \mathrm{MHz}, \mathrm{CDCl}_{3}\right): \delta \mathrm{ppm} 173.5,146.6,138.7,138.1,129.8$, 129.7, 129.6, 129.23, 129.20, 129.1, 129.0, 98.3, 81.2, 79. 7, 75.7, 73.3, 70.1, 69.4, 63.2, 55.3, 33.5, 32.6, 29.3, 27.6, 13.8, 9.5; TOF HRMS (DART): $\mathrm{m} / z$ for $\mathrm{C}_{38} \mathrm{H}_{59} \mathrm{O}_{7} \mathrm{Sn}[\mathrm{M}+\mathrm{H}]^{+}$calcd. 747.3291, found 747.3244 .

\subsection{Methyl 2,3-di-O-benzyl-4-O-(5-iodo-4E-penten)oyl-6-O-[(5-tributyl-stannyl)-4E-penten]oyl- $\alpha$ - $D$ -} glucoside 15

To a cooled solution of DCC (270 $\mathrm{mg}, 1.3 \mathrm{mmol})$ and DMAP (14 mg, $0.1 \mathrm{mmol}$ ) in anhydrous $\mathrm{CH}_{2} \mathrm{Cl}_{2}(15 \mathrm{~mL})$ at $0{ }^{\circ} \mathrm{C}$ was added $4 E$-5-iodopentenoic acid 14 (270 mg, $\left.1.2 \mathrm{mmol}\right)$. The resulting solution was stirred at same temp for $30 \mathrm{~min}$ before a solution of vinylstannane 13 (900 mg, 1.2 mmol) in anhydrous $\mathrm{CH}_{2} \mathrm{Cl}_{2}(15 \mathrm{~mL})$ was introduced. The mixture was allowed to raise to room temperature slowly and stirred overnight. The reaction mixture was then filtered through a pad of Celite, washed with $\mathrm{CH}_{2} \mathrm{Cl}_{2}$ and the filtrate was evaporated to give the crude product which on silica gel column chromatography (4:1 Hex: EtOAc) provided ester 15 (870 mg, 76\%) as colorless liquid. Rf 0.35 (4:1 Hex: EtOAc); $[\alpha]_{D}{ }^{20}:+26.4\left(c 0.8, \mathrm{CHCl}_{3}\right) ;{ }^{1} \mathrm{H}$ NMR $\left(400 \mathrm{MHz}, \mathrm{CDCl}_{3}\right): \delta$ ppm 7.34-7.26 $(\mathrm{m}, 10 \mathrm{H}), 6.48-6.41(\mathrm{~m}, 1 \mathrm{H}), 6.05(\mathrm{~d}, J=14.5 \mathrm{~Hz}, 1 \mathrm{H}), 5.93(\mathrm{~s}, 2 \mathrm{H}), 4.97(\mathrm{t}, J=9.9 \mathrm{~Hz}, 1 \mathrm{H}), 4.89$ $(\mathrm{d}, J=11.6 \mathrm{~Hz}, 1 \mathrm{H}), 4.79(\mathrm{~d}, J=12.0 \mathrm{~Hz}, 1 \mathrm{H}), 4.65-4.59(\mathrm{~m}, 3 \mathrm{H}), 4.18(\mathrm{dd}, J=12.3,5.1 \mathrm{~Hz}, 1 \mathrm{H})$, 4.00 (dd, $J=12.2,1.7 \mathrm{~Hz}, 1 \mathrm{H}$ ), 3.91 ( t, $J=9.4 \mathrm{~Hz}, 1 \mathrm{H}$ ), 3.83 (ddd, $J=10.2,5.1,1.8 \mathrm{~Hz}, 1 \mathrm{H}$ ), 3.58 ( $\mathrm{dd}, J=9.4,3.4 \mathrm{~Hz}, 1 \mathrm{H}), 3.39(\mathrm{~s}, 3 \mathrm{H}), 2.46-2.38(\mathrm{~m}, 4 \mathrm{H}), 2.27-2.20(\mathrm{~m}, 1 \mathrm{H}), 1.53-1.41(\mathrm{~m}, 6 \mathrm{H})$,

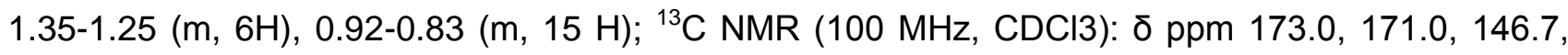
144.0, 138.6, 137.9, 128.8, 128.6, 128.5, 128.3, 128.2, 127.9, 127.7, 98.3, 79.7, 79.2, 75.5, 73.7, $69.8,67.7,62.2,55.5,33.4,32.6,32.5,31.0,29.3,29.2,27.4,13.8,9.5$; TOF HRMS (DART): $\mathrm{m} / z$ for $\mathrm{C}_{26} \mathrm{H}_{45} \mathrm{O}_{8} \mathrm{Sn}[\mathrm{M}+\mathrm{H}]^{+}$calcd. 955.2678, found 955.2642.

\subsection{Macrodilactone 8}

To a degassed solution of ester 15 (88 $\mathrm{mg}, 0.09 \mathrm{mmol})$ in anhydrous DMF (135 mL, c $\approx 7 \times 10-4 \mathrm{M})$ were added $\mathrm{Pd}_{2}(\mathrm{dba})_{3}, \mathrm{CHCl}_{3}(30 \mathrm{mg}, 0.03 \mathrm{mmol}), \mathrm{Ph}_{3} \mathrm{As}$ (36 mg, $0.11 \mathrm{mmol}$ ), and DIPEA (228 $\mu \mathrm{L}$, $1.9 \mathrm{mmol}$ ) successively at room temperature and the resulting mixture was stirred at same temperature for $24 \mathrm{~h}$. The reaction mixture was diluted with $\mathrm{CH}_{2} \mathrm{Cl}_{2}(60 \mathrm{~mL})$, washed with water $(3 \mathrm{x}$ $50 \mathrm{~mL})$. The aqueous parts were separated and extracted with $\mathrm{CH}_{2} \mathrm{Cl}_{2}(4 \times 30 \mathrm{~mL})$. The combined organic parts were washed with brine, dried over anhydrous $\mathrm{Na}_{2} \mathrm{SO}_{4}$, filtered, and concentrated to give the crude product. Silica gel column chromatography $(3: 1 \mathrm{Hex}$ : EtOAc) of the crude residue resulted macrocycle 8 (20 mg, 42\%) as a white solid. Rf $0.25\left(2: 1 \mathrm{Hex}\right.$ : EtOAc); $\mathrm{mp} 115^{\circ} \mathrm{C}$; $[\alpha]_{\mathrm{D}}{ }^{20}$ : +10.8 (c 0.5, $\left.\mathrm{CHCl}_{3}\right) ;{ }^{1} \mathrm{H} \mathrm{NMR}\left(400 \mathrm{MHz}, \mathrm{CDCl}_{3}\right.$ ): $\delta$ ppm 7.35-7.27 (m, 10H), 6.03 (dd, J = 15.0, 10.5 $\mathrm{Hz}, 1 \mathrm{H}), 5.88$ (dd, $J=15.0,10.5 \mathrm{~Hz}, 1 \mathrm{H}), 5.56-5.48(\mathrm{~m}, 1 \mathrm{H}), 5.45-5.38(\mathrm{~m}, 1 \mathrm{H}), 4.86(\mathrm{~d}, J=11.4 \mathrm{~Hz}$, $1 \mathrm{H}), 4.79(\mathrm{~d}, J=9.2 \mathrm{~Hz}, 1 \mathrm{H}), 4.76(\mathrm{~d}, J=6.0 \mathrm{~Hz}, 1 \mathrm{H}), 4.65(\mathrm{~d}, J=3.6 \mathrm{~Hz}, 1 \mathrm{H}), 4.62(\mathrm{~d}, J=3.0 \mathrm{~Hz}$, $1 \mathrm{H}), 4.57(\mathrm{~d}, J=3.5 \mathrm{~Hz}, 1 \mathrm{H}), 3.96(\mathrm{t}, J=9.3 \mathrm{~Hz}, 1 \mathrm{H}), 3.87(\mathrm{dd}, J=11.5,7.6 \mathrm{~Hz}, 1 \mathrm{H}), 3.80(\mathrm{dd}, J=$ 
10.0, $8.0 \mathrm{~Hz}, 1 \mathrm{H}), 3.67$ (d, $J=11.4 \mathrm{~Hz}, 1 \mathrm{H}), 3.54(\mathrm{dd}, J=9.6,3.5 \mathrm{~Hz}, 1 \mathrm{H}), 3.43(\mathrm{~s}, 3 \mathrm{H}), 2.45-2.19$ $(\mathrm{m}, 8 \mathrm{H}) ;{ }^{13} \mathrm{C}$ NMR $\left(100 \mathrm{MHz}, \mathrm{CDCl}_{3}\right): \delta \mathrm{ppm} 173.5,171.0,138.6,138.0,133.2,131.9,130.1,129.8$, 128.6, 128.5, 128.2, 128.1, 127.9, 127.7, 98.0, 79.5, 79.2, 75.5, 73.6, 70.5, 68.2, 64.8, 55.5, 36.0, 34.6, 29.9, 27.7; TOF HRMS (DART): $\mathrm{m} / \mathrm{z}$ for $\mathrm{C}_{31} \mathrm{H}_{40} \mathrm{NO}_{8}\left[\mathrm{M}+\mathrm{NH}_{4}\right]^{+}$calcd. 554.2754, found 554.2727.

\subsection{Epoxy-macrodilactone 16}

To a solution of macrodilactone $8(43 \mathrm{mg}, 0.08 \mathrm{mmol})$ in acetone $-\mathrm{H}_{2} \mathrm{O}-\mathrm{CH}_{2} \mathrm{Cl}_{2}(1: 1: 1,5 \mathrm{~mL})$ was added excess amount of $\mathrm{NaHCO}_{3}(90 \mathrm{mg}, 1.06 \mathrm{mmol})$ and Oxone $(67 \mathrm{mg}, 0.22 \mathrm{mmol})$ at $0{ }^{\circ} \mathrm{C}$. The resultant mixture was slowly raised to room temperature and stirred until complete consumption of starting material. The reaction mixture was diluted with water $(4 \mathrm{~mL})$, and extracted with $\mathrm{CH}_{2} \mathrm{Cl}_{2}(3 \mathrm{x}$ $10 \mathrm{~mL}$ ). The combined extracts were dried over anhydrous $\mathrm{Na}_{2} \mathrm{SO}_{4}$, filtered, and concentrated in vacuo. The flash column chromatography (2:3 Hexane: EtOAc) of the crude residue provided macrocyclic epoxide 16 (30 mg, 67\%) as white solid. Rf $0.25\left(1: 1 \mathrm{Hex}\right.$ : EtOAc); $\mathrm{mp} 132{ }^{\circ} \mathrm{C}$; $[\alpha]_{\mathrm{D}}{ }^{20}$ : +17.1 (c 0.5, $\left.\mathrm{CHCl}_{3}\right) ;{ }^{1} \mathrm{H}$ NMR $\left(400 \mathrm{MHz}, \mathrm{CDCl}_{3}\right): \delta$ ppm 7.36-7.27 (m, 10H), 5.84-5.77 (m, $\left.1 \mathrm{H}\right), 5.18$ (dd, $J=15.6,9.2 \mathrm{~Hz}, 1 \mathrm{H}), 4.87(\mathrm{~d}, J=11.7 \mathrm{~Hz}, 1 \mathrm{H}), 4.81-4.74(\mathrm{~m}, 2 \mathrm{H}), 4.65(\mathrm{~d}, J=8.3 \mathrm{~Hz}, 1 \mathrm{H})$, $4.62(\mathrm{~d}, J=8.0 \mathrm{~Hz}, 1 \mathrm{H}), 4.56(\mathrm{~d}, J=3.4 \mathrm{~Hz}, 1 \mathrm{H}), 3.99-3.93(\mathrm{~m}, 2 \mathrm{H}), 3.82-3.76(\mathrm{~m}, 2 \mathrm{H}), 3.54(\mathrm{dd}, J=$ 9.5, 3.4 Hz, 1H), 3.44 (s, 3H), 2.93 (dd, J = 9.2, $1.4 \mathrm{~Hz}, 1 \mathrm{H}$ ), $2.83(\mathrm{~d}, J=10.3 \mathrm{~Hz}, 1 \mathrm{H}), 2.48-2.25$ (m, $8 \mathrm{H}), 1.48-1.37(\mathrm{~m}, 1 \mathrm{H}) ;{ }^{13} \mathrm{C}$ NMR (100 MHz, CDCl3): $\delta \mathrm{ppm} 173.2,171.5,146.7,144.0,139.8$, 128.9, 128.8, 128.3, 126.5, 76.4, 73.2, 60.5, 35.4, 33.6, 33.1, 32.7, 31.2, 29.2, 27.3, 13.8, 9.5; TOF HRMS (DART): $m / z$ for $\mathrm{C}_{31} \mathrm{H}_{37} \mathrm{O}_{9}[\mathrm{M}+\mathrm{H}]^{+}$calcd. 553.2438, found 553.2412.

\subsection{Dimethyl (4S,5S-epoxy)-dec-6E-enedioate 17}

Macrocyclic epoxide 16 (30 mg, $0.05 \mathrm{mmol}$ ) was dissolved in a solution of $\mathrm{NaOMe}$ in $\mathrm{MeOH}$ (2 mL, $0.5 \mathrm{mg} / \mathrm{mL}$ ) and the mixture was stirred for $72 \mathrm{~h}$ at room temperature. The reaction mixture was concentrated under reduced pressure, the residue was diluted with EtOAc and then with water. The water part was separated and extracted with EtOAc $(3 \times 10 \mathrm{~mL})$. The combined organic parts were dried over anhydrous $\mathrm{Na}_{2} \mathrm{SO}_{4}$, filtered, and concentrated in vacuo. The flash column chromatography (6:1 Hexane: EtOAc) of the crude residue afforded diester (-)-17 (9 mg, 74\%) as colorless liguid. Rf 0.30 (4:1 Hex: EtOAc); $[\alpha]_{D}^{20}:-23.2$ (c 0.6, $\left.\mathrm{CHCl}_{3}\right) ;{ }^{1} \mathrm{H} \mathrm{NMR}\left(400 \mathrm{MHz}, \mathrm{CDCl}_{3}\right): \delta$ ppm 5.93-5.86 (m, 1H), 5.22 (dd, $J=15.2,7.9 \mathrm{~Hz}, 2 \mathrm{H}$ ), $3.68(\mathrm{~s}, 3 \mathrm{H}), 3.67$ (s, 3H), 3.09 (dd, $J=7.8$, $1.8 \mathrm{~Hz}, 1 \mathrm{H}$ ), 2.87 (ddd, $J=6.5,4.6,2.0 \mathrm{~Hz}, 1 \mathrm{H}$ ), 2.45 (t, $J=7.9 \mathrm{~Hz}, 2 \mathrm{H}$ ), 2.41-2.37 (m, 4H), 2.04$1.96(\mathrm{~m}, 1 \mathrm{H}), 1.81-1.73(\mathrm{~m}, 1 \mathrm{H}) ;{ }^{13} \mathrm{C}$ NMR $\left(100 \mathrm{MHz}, \mathrm{CDCl}_{3}\right): \delta \mathrm{ppm} 173.3,134.4,128.5,59.2,58.5$, 51.8, 51.7, 33.4, 30.2, 27.6, 27.3; TOF HRMS (DART): $\mathrm{m} / \mathrm{z}$ for $\mathrm{C}_{12} \mathrm{H}_{19} \mathrm{O}_{5}[\mathrm{M}+\mathrm{H}]^{+}$calcd. 243.1232, found 243.1236 .

\section{Acknowledgements}

The NSF supported this work through a grant to MWP (CHE-0957626). 400MHz/100MHz NMR spectra were collected on an instrument that was upgraded by an NSF-CRIF grant (CHE-0947019). 
The Chemistry Instrumentation Center at Yale University is acknowledged for collection of X-ray data on 8. Kelli Rutledge is acknowledged for help in developing the conformational maps shown in Figure 4. 


\section{References}

1. J. Xie, N. Bogliotti, Chem. Rev. 114 (2014) 7678-7739.

2. A. Fürstner, Eur. J. Org. Chem. (2004) 943-958.

3. D. V. Jarikote, P.V. Murphy, Eur. J. Org. Chem. (2010) 4959-4970.

4. Y. Kim, M.A. Arai, T. Arai, J.O. Lamenzo, E.F. Dean, N. Patterson, P.A. Clemons, S. L. Schreiber, J. Am. Chem. Soc. 126, (2004) 14740-14745.

5. A. Fürstner, K. Radkowski, J. Grabowski, C. Wirtz, R. Mynott, J. Org. Chem. 65 (2000) 8758-8762.

6. S.N. Das, R. Rana, S. Chatterjee, G.S. Kumar, S.B. Mandal, J. Org. Chem. 79 (2014) 9958-9969.

7. A. Hussain, L.M. Rao, D.K. Sharma, A.K. Tripathi, B. Singh, D. Mukherjee, RSC Adv. 3 (2013) 19899-19904.

8. A. Hussain, S.K. Yousuf, D.K. Sharma, L.M. Rao, B. Singh, D. Mukherjee, Tetrahedron 69 (2013) 5517-5524.

9. A. Hussain, S.K. Yousuf, D. Kumar, M. Lambu, B. Singh, S. Maity, D. Mukherjee, Adv. Synth. Catal. 354 (2012) 1933-1940.

10. M.A. Potopnyk, P. Cmoch, S. Jarosz, Org. Lett. 14 (2012) 4258-4261.

11. A. Ajay, S. Sharma, M.P. Gupt, V. Bajpai, B. Kumar, M.P. Kaushik, R. Konwar, R.S. Ampapathi, R.P. Tripathi, Org. Lett. 14 (2012) 4306-4309.

12. A. Allam, L. Dupont, J.-B.Behr, R. Plantier-Royon, Eur. J. Org. Chem. (2012) 817-823.

13. B. Ruttens, P. Blom, S. Van Hoof, I. Hubrecht, J. Van der Eycken, J. Org. Chem. 72 (2007) 5514-5522.

14. R.T. Desmond, A.N. Magpusao, C. Lorenc, J.B. Alverson, N. Priestley, M.W. Peczuh, Beilstein J. Org. Chem. 10 (2014) 2215-2221.

15. A.N. Magpusao, R.T. Desmond, K.J. Billings, G. Fenteany, M.W. Peczuh, Bioorg. Med. Chem. Lett. 20 (2010) 5472-5476.

16. W.S. Fyvie, M.W. Peczuh, J. Org. Chem. 73 (2008) 3626-3629.

17. W.S. Fyvie, M.W. Peczuh, Chem. Commun. (2008) 4028-4030.

18. J. Ma, M.W. Peczuh, J. Org. Chem. 78 (2013) 7414-7422.

19. J. Ma, R. Vannam, D.W. Terwilliger, M.W. Peczuh, Tetrahedron Lett. 55 (2014) 4255-4259.

20. A.N. Mapusao, K. Rutledge, B.Q. Mercado, M.W. Peczuh, Org. Biomol. Chem. 13 (2015) 5086-5089.

21. A.N. Magpusao, K.Rutledge, T. Hamlin, T. J.-M. Lawrence, B.Q. Mercado, N.E. Leadbeater, M.W. Peczuh, Chem. Eur. J. 22 (2016) 6001-6011.

22. D. Si, M.W. Peczuh, Org. Biomol. Chem. 13 (2015) 6463-6467.

23. B. Elchert, J. Li, J. Wang, Y. Hui, R. Rai, R. Ptak, P. Ward, J. Y. Takemoto, M. Bensaci, C.-W. T. Chang J. Org. Chem. 69 (2004) 1513-1523.

24. H.X. Zhang, F. Guibé, G. Balavoine, J. Org. Chem. 55 (1990) 1857-1867. 
25. H.J. Reich, E.K. Eisenhart, R.E. Olson, M.J. Kelly, J. Am. Chem. Soc. 108 (1986) 108, 77917800 .

26. A. Francais, A. Leyva, G. Etxebarria-Jardi, S.V. Ley, Org. Lett. 12 (2010) 340-343.

27. A.A. Sabino, R.A. Pilli, Tetrahedron Lett. 43 (2002) 2819-2821.

28. Y. Wu, J. Gao, Org. Lett.10 (2008) 1533-1536.

29. M. Apparu, P. Demenge, D. Fagret, C. Ghezzi, S. Majid, J.-P. Mathieu, L. Manuclaire, R. Pasqualini, M. Vidal, PCT Int. Appl. WO 9600717 A1, Jan. 11, 1996, 56 pp.; Chem. Absrt. 1996, 124, 288981.

30. Q. Chen, D. Schweitzer, J. Kane, V.J. Davisson, P. Helquist, J. Org. Chem. 76 (2011) 51575169.

31. R. Stenutz, I. Carmichael, G. Widmalm, A.S. Serianni, J. Org. Chem. 67 (2002) 949-958.

32. C.B. Barnett, K.J. Naidoo, J. Phys. Chem. B 112 (2008) 15450-15459.

33. J. Gonzalez-Outeiriño, K.N. Kirschner, S. Thobhani, R.J. Woods, Can. J. Chem. 84 (2006) 569-579.

34. K.N. Kirschner, R.J. Woods, Proc. Natl. Acad. Sci. 98 (2001) 10541- 10545.

35. L.P. Samankumara, S.J. Dorazio, J. Akhigbe, R. Li, A. Nimthong-Roldán, M. Zeller, C. Brückner, Chem. Eur. J. 21 (2015) 11118-11128.

36. W.C. Still, I. Galynker, Tetrahedron 7 (1981) 3981-3996.

37. W.C. Still, V.J. Novack, J. Am. Chem. Soc. 106 (1984) 1148-1149.

38. W.C. Still, A.G. Romero, J. Am. Chem. Soc. 108 (1986) 2105-2106.

39. S. Arns, M.-E. Lebrun, C.M. Grisé, I. Denissova, L. Barriault, J. Org. Chem. 72 (2007) 93149322.

40. C. Han, S. Rangarajan, A.C. Voukides, A.B. Beeler, R. Johnson, J.A. Porco, Org. Lett. 11 (2009) 413-416.

41. M. Frohn, M. Dalkiewicz, Y. Tu, Z.-X. Wang, Y. Shi, J. Org. Chem. 63 (1998) 2948-2953.

42. C.P. Burke, Y. Shi, Angew. Chem. Int. Ed. 45 (2006) 4475-4478.

43. F. Giordanetto, J. Kihlberg, J. Med. Chem. 57 (2014) 278-295.

44. R. O'Shea, H.E. Moser, J. Med. Chem. 51 (2008) 2871-2878. 
Synthesis and structure of a carbohydrate-fused [15]-macrodilactone Debjani Si and Mark W. Peczuh*
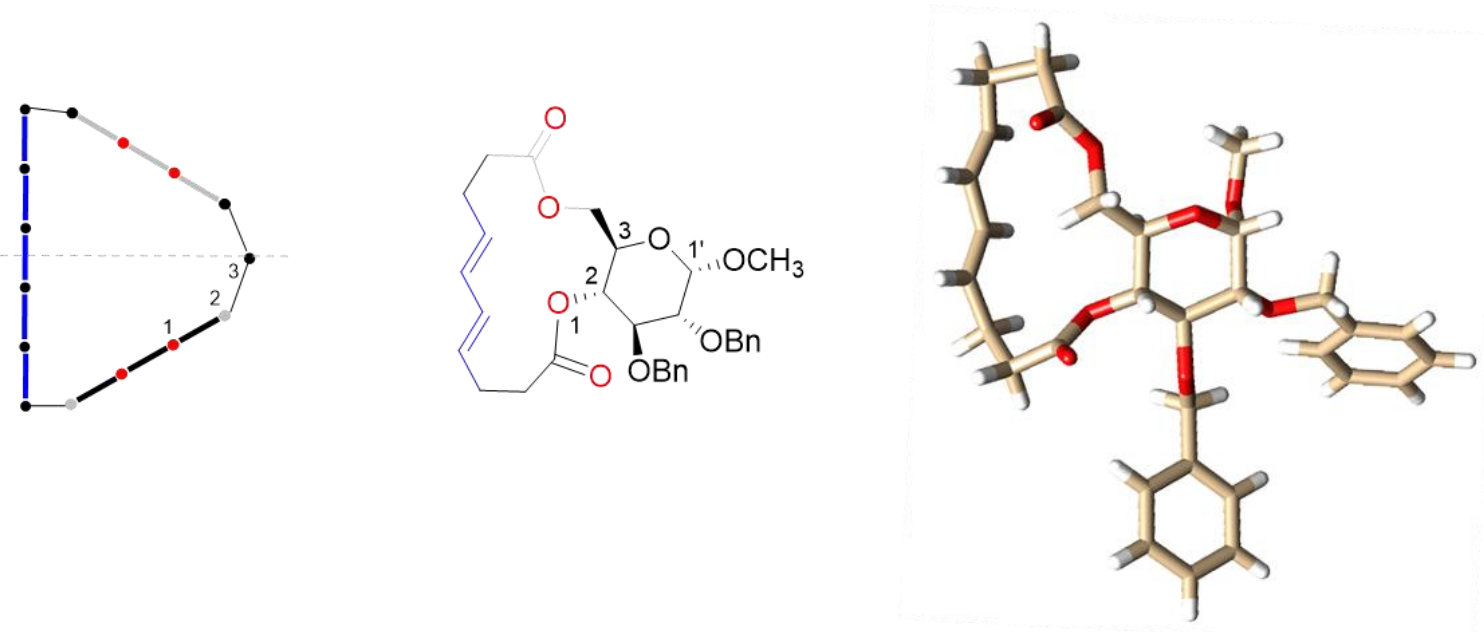